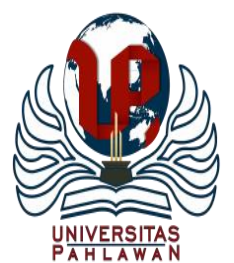

Edukatif : Jurnal Ilmu Pendidikan Volume 3 Nomor 4 Tahun 2021 Halm 1922 - 1935

EDUKATIF: JURNAL ILMU PENDIDIKAN

Research \& Learning in Education

https://edukatif.org/index.php/edukatif/index

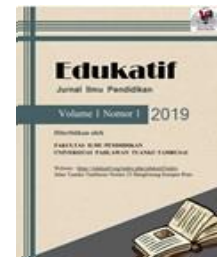

\title{
Keefektifan Penggunaan Media Gambar Seri dalam Pembelajaran Menulis Teks Prosedur pada Siswa Sekolah Menengah Pertama
}

\author{
Avillia Nuraenita $^{1 凶}$, Wienike Dinar Pratiwi ${ }^{2}$, Een Nurhasanah ${ }^{3}$ \\ Universitas Singaperbangsa Karawang, Indonesia ${ }^{1,2,3}$ \\ E-mail : avillianuraenita04@gmail.com ${ }^{1}$, wienike.dinar@ fkip.unsika.ac.id ${ }^{2}$, \\ een.nurhasanah@staff.unsika.ac.id ${ }^{3}$
}

\begin{abstract}
Abstrak
Penelitian ini bertujuan untuk mengetahui keefektifan penggunaan media gambar seri dalam pembelajaran menulis teks prosedur pada siswa kelas VII SMP Negeri 3 Cikarang Timur. Pada penelitian ini peneliti menggunakan pendekatan kuantitatif karena data-data disajikan berupa angka dan dianalisis menggunakan bentuk statis. Metode penelitian yang digunakan adalah metode pre-experimental desains. Adapun perlakuan media gambar yang diuji cobakan pada akhir tes atau disebut posttest. Jadi, keterampilan menulis teks prosedur akan diberikan pada awal tes (pretest) sebelum diberikan perlakuan, lalu tes keterampilan menulis teks prosedur selanjutnya diberikan setelah adanya perlaku (posttest). Adapun populasi yang digunakan dalam penelitian ini adalah kelas VII di Sekolah Menengah Pertama Negeri 3 Cikarang Timur. Pemilihan sampel menggunakan Sampling Purposive, maka berdasarkan hal tersebut peneliti disarankan oleh guru bidang studi yang bersangkutan untuk mengambil sampel pada kelas VII.1 dengan jumlah siswa 39. Desain penelitian ini menggunakan one-group pretest-posttest design. Berdasarkan hasil pengolahan data, tampak bahwa hasil tes kemampuan siswa kelas VII.1 Sekolah Menengah Pertama Negeri 3 Cikarang Timur dalam keterampilan menulis teks prosedur berada pada kategori baik dengan nilai rata-rata 75.
\end{abstract}

Kata Kunci: Pembelajaran Bahasa Indonesia, Keterampilan Menulis, Media Pembelajaran.

\begin{abstract}
This study aims to determine the effectiveness of using serial image media in learning to write procedural texts for seventh grade students of SMP Negeri 3 Cikarang Timur. In this study, the researcher used a quantitative approach because the data were presented in the form of numbers and analyzed using a static form. The research method used is the pre-experimental design method. The treatment of the image media that was tested at the end of the test or called the posttest. So, the procedural text writing skills will be given at the beginning of the test (pretest) before being given treatment, then the procedural text writing skills test will be given after the treatment (posttest). The population used in this study is class VII at the State Junior High School 3 Cikarang Timur. The sample selection used purposive sampling, so based on this, the researcher was advised by the teacher of the field of study concerned to take a sample in class VII.1 with 39 students. The design of this study used a one-group pretest-posttest design. Based on the results of data processing, it appears that the test results of grade VII.1 students of SMP Negeri 3 Cikarang Timur in writing procedural text skills are in the good category with an average score of 75 .
\end{abstract}

Keywords: Indonesian Language Learning, Writing Skills, Learning Media.

Copyright (c) 2021 Avillia Nuraenita, Wienike Dinar Pratiwi, Een Nurhasanah

$\triangle$ Corresponding author

Email : avillianuraenita04@gmail.com

DOI : https://doi.org/10.31004/edukatif.v3i4.1105

ISSN 2656-8063 (Media Cetak)

ISSN 2656-8071 (Media Online) 
1923 Keefektifan Penggunaan Media Gambar Seri dalam Pembelajaran Menulis Teks Prosedur pada Siswa Sekolah Menengah Pertama - Avillia Nuraenita, Wienike Dinar Pratiwi, Een Nurhasanah

DOI: https://doi.org/10.31004/edukatif.v3i4.1105

\section{PENDAHULUAN}

Pendidikan dalam arti luas mengandung makna bahwa pendidikan tidak hanya berkembang dalam satu lembaga pendidikan yang disebut sekolah. Menurut (H. Chomaidi \& Salamah, 2018) pendidikan dapat diartikan sebagai pengaruh dinamis dalam perkembangan rohani, jasmani, susila, keterampilan, dan rasa sosial yang mampu mengembangkan pribadi integral. Menurut (Muhammad Anwar, 2015) pendidikan sebagai usaha manusia untuk menumbuhkan dan mengembangkan potensi-potensi pembawaan baik jasmani maupun rohani sesuai dengan nilai-nilai yang ada dalam masyarakat dan kebudayaan. Menurut (Anselmus, 2016) pendidikan dilengkapi dan diadaptasi menjadi upaya sadar dan terencana oleh pendidik untuk mewujudkan suasana belajar dan proses pembelajaran agar peserta didik secara aktif mengembangkan potensi diri sehingga memiliki kekuatan spiritual keagamaan, pengendalian diri, kepribadian, kecerdasan, akhlak mulia, serta keterampilan yang diperlukan dirinya, masyarakat bangsa, dan negara. Pendidikan sebagai pengalaman belajar mempunyai bentuk suasana, dan pola yang beraneka ragam. Pendidikan merupakan suatu pengalaman belajar yang terentang dari bentuk-bentuk yang terjadi dengan sendirinya dalam hidup yang kehadirannya tidak disengaja.

Berbicara mengenai keterampilan berbahasa, keterampilan berbahasa mempunyai empat komponen, yaitu Keterampilan Menyimak (Listening Skills), Keterampilan Berbicara (Speaking Skills), Keterampilan Membaca (Reading Skills), dan Keterampilan Menulis (Writing Skills). Masing-masing keterampilan itu berkaitan erat dengan proses-proses berpikir yang melandasi bahasa. Bahasa seseorang mencerminkan pikirannya. Menurut (Dalman .H, 2016) menulis merupakan suatu proses yang kemampuan, pelaksanaan, dan hasil diperleh secara bertahap. Menurut (Budiyono, 2010) menulis adalah tahapan-tahapan kegiatan dalam rangka menghasilkan suatu tulisan, yaitu prapenulisan, penulisan draf, dan revisi. Menurut (Gereda Agustinus, 2020) kemampuan dan kecekapan menggunakan bahasa yang mencakupi keterampilan mendengarkan atau menyimak, berbicara, membaca, dan menulis.

Setiap orang mempunyai keahlian dalam berpikir dengan baik, tetapi tidak semua orang mempunyai kemampuan dalam berbahasa dengan sangat baik. Sesuatu yang sudah kita pikirkan belum tentu akan kita ucapkan dan kerjakan, tetapi sesuatu yang sudah kita ucapkan itulah yang kita pikirkan dan lakukan. Dengan bahasa dan berbahasa kita mampu menentukan jati diri pada karakter, dan cara berpikir seseorang. Keahlian seseorang ketika berpikir dan berbahasa sebenarnya bisa menguatkan, yaitu dengan melakukan usaha/aktivitas atau keterampilan yang dapat melatih diri kita agar terampil. Menurut (Hendra, 2018) kemampuan adalah kapasitas seseorang dalammelakukan tugas dari suatu pekerjaan yang dilakukan. Bisa juga dikatakan bahwa kemampuan adalah sebuah penilaian akhir dari apa yang dapat dilakukan seseorang untuk mencapai satu tujuan. Menurut (Sholeh \& Afriani, 2016) kemampuan menulis adalah kemampuan seseorang untuk menuangkan buah pikiran, ide, gagasan, dengan mempergunakan rangkaian bahasa tulis yang baik dan benar.

Keterampilan menulis sangat dibutuhkan dalam kehidupan sehari-hari. Menurut (Munirah, 2015) menulis merupakan keterampilan mengomunikasikan pikiran, gagasan, dann informasi yang harus dilatih sejak dini. Dengan keterampilan menulis, seseorang akan mudah mengungkapkan suatu ide, pikiran, dan perasaan kepada orang lain melalui sebuah tulisan. Mereka mampu berkomunikasi dengan orang lain tanpa harus berhadapan secara langsung dengan orang yang diajak berkomunikasi. Keterampilan menulis melambangkan kecakapan yang tidak datang secara tiba-tiba.

Setiap keterampilan itu saling berkaitan dengan kerampilan yang lainnya dengan cara yang beragam. Keterampilan itu sangat kuat dengan sistem yang mendasari bahasa. Jadi, semakin terampil seseorang berbahasa, maka semakin cerah dan jelas jalan pikirannya. Menurut (Tarigan, 2008) menulis merupakan kegiatan berbahasa yang dipergunakan untuk berkomunikasi secara tidak langsung. Menurut (Dewi Ika Fitryana, 2011) menulis menggambarkan suatu kegiatan yang bermanfaat dan ekspresif. Menulis merupakan 
1924 Keefektifan Penggunaan Media Gambar Seri dalam Pembelajaran Menulis Teks Prosedur pada Siswa Sekolah Menengah Pertama - Avillia Nuraenita, Wienike Dinar Pratiwi, Een Nurhasanah

DOI: https://doi.org/10.31004/edukatif.v3i4.1105

suatu keterampilan berbahasa yang dipergunakan untuk berkomunikasi secara tidak langsung, tidak secara tatap muka dengan orang lain.

Selain itu, menurut (Zulfikar Fu'ad, 2008) juga mengungkapkan bahwa terdapat delapan hal yang harus diperhatikan dalam menulis, yaitu: (1) fokus, (2) konsisten (3) pengembangan ide yang menarik, (4) pembacaan model, (5) pertahankan diri sebagai penulis, (6) penjelasan, (7) tone atau nada, (8) pengembangan paragraf.

Menurut (Argiandini, 2019) keterampilan menulis merupakan bentuk atau wujud kemampuan atau keterampilan berbahasa yang paling akhirdikuasai pembelajar bahasa setelah mendengarkan, berbicara, dan membaca. Menurut (Ulfa et al., 2019) menulis merupakan proses penuangan ide atau gagasan dalam bentuk paparan bahasa tulis berupa rangkaian simbol-simbol bahasa Dalam keterampilan berbahasa, salah satunya menulis. Masih banyak dikalangan masyarakat terutama anak-anak Sekolah Menengah Pertama, mereka masih sangat kurang pengetahuan tentang kepenulisan. Penulis mengaitkannya dengan pembelajaran Bahasa Indonesia yaitu Teks Prosedur, seperti yang kita ketahui. Teks prosedur merupakan teks yang berisi tentang langkah-langkah dalam membuat atau melakukan sesuatu secara berentet. Tujuan dari teks prosedur adalah untuk memudahkan para pembaca dan pendengar agar melakukan sesuatu dengan benar sehingga mendapatkan hasil yang sesuai.

Proses pembelajaran tersebut didukung oleh media karena hakikatnya media proses komunikasi, penyampaian pesan dari pengantar ke penerima. Menurut (Mustofa Abi Hamid, 2020) media dalam proses pembelajaran merupakan perantara atau pengantar sumber pesan dan penerima pesan, merangsang pikiran, perasaan, perhatian, dan kemauan sehingga terdorong sehingga terlibat dalam pembelajaran. Menurut (Wibowo et al., 2020) media adalah berbagai jenis komponen dalam lingkungan siswa yang dapat merangsang untuk belajar. Menurut (Haryanti, 2010) media gambar seri merupakan salah satu media visual yang sering digunakan dalam menyampaikan materi pelajaran yang dapat memberikan nilai yang sangat berarti, terutama dalam membentuk pengertian baru dan untuk memperjelas pengertian tentang sesuatu. Adapun fungsi dalam media pembelajaran yaitu sebagai pembawa informasi dari sumber (guru) menuju penerima (siswa). Kegiatan berinteraksi antara murid dengan lingkungannya, fungsi media dapat ditemukan menurut adanya keunggulan dan hambatan yang mungkin menimbulkan proses pembelajaran.

Menurut (Cepy, 2012) media pembelajaran merupakan wadah dari pesan, materi yang ingin disampaikan adalah pesan pembelajaran, tujuan yang ingin dicapai ialah proses pembelajaran. Membahas mengenai media, peneliti memakai media dua dimensi atau sebutan umum untuk alat peraga yang hanya memiliki ukuran panjang dan lebar yang berbeda pada suatu bidang datar. Media gambar dua dimensi mencakup grafis, media berbentuk papan, dan media cetak yang penampilan isinya tercantum dua dimensi. Membahas mengenai media, peneliti memakai media dua dimensi atau sebutan umum untuk alat peraga yang hanya memiliki ukuran panjang dan lebar yang berbeda pada suatu bidang datar. Media gambar dua dimensi mencakup grafis, media berbentuk papan, dan media cetak yang penampilan isinya tercantum dua dimensi. Media grafis merupakan penyampaian dengan cara visual yang menggabungkan titik-titik, garis-garis, gambar-gambar, tulisan-tulisan, atau simbol visual yang lain dengan maksud untuk mengihtisarkan, menggambar, dan merangkum suatu ide, data, atau kejadian. Komponen di dalam media grafis kadang kala disebut juga sebagai fragmen visual, terdiri dari: titik, garis, bidang, bentuk, ruang, warna, dan tekstur.

Secara umum, keunggulan dari media gambar seri yaitu sangat mudah ketika dipergunakan dan dibuat. Kekurangan dari gambar seri yaitu hanya mengutamakan indera mata, terlalu berbelit-belit, dan ukurannya terbatas untuk kelompok besar. Untuk mencegah berbagai kekurangan gambar seri, jadi gambar dibuat sesederhana mungkin dikarenakan gambar yang terlalu detail dapat mengganggu pemfokusan siswa. Jadi, media pembelajaran adalah segala sesuatu yang dapat dipergunakan untuk menyalurkan pesan (bahan pembelajaran) kepada siswa, kemudin dapat menumbuhkan ketertarikan, minat, konsentrasi, dan perasaan siswa dalam urusan belajar untuk menggapai tujuan belajar. 
1925 Keefektifan Penggunaan Media Gambar Seri dalam Pembelajaran Menulis Teks Prosedur pada Siswa Sekolah Menengah Pertama - Avillia Nuraenita, Wienike Dinar Pratiwi, Een Nurhasanah

DOI: https://doi.org/10.31004/edukatif.v3i4.1105

Teks prosedur ini penulis menggunakan media gambar, sehingga anak-anak dapat tertarik untuk membuat teks prosedur tersebut. Jadi penulis memberikan salah satu gambar yang sudah dibuat sebelumnya untuk diberikan kepada anak-anak, dikarenakan situasi saat ini sedang pandemi peneliti memberikan media gambar melelui laman eketronik (Website) yang telah disediakan, lalu diharapkan anak-anak mampu untuk membuat teks prosedur sesuai dengan gambar yang telah diberikan. Diharapkan dengan menggunakan media gambar, proses pembelajaran dapat efektif dan dapat di mengerti oleh banyak siswa.

Adapun penelitian yang terkait dengan keterampilan menulis teks prosedur dan terdapat beberapa perbedaan. Karlina Megawati penelitian tentang Peningkatan Kemampuan Menulis Teks Prosedur Menggunakan Metode Field Trip Pada Siswa Kelas VIII 5 SMP Negeri 2 Lingsar Tahun Pembelajaran 2016/2017, perbedaan yang dilakukan pertama adalah metode yang digunakan, Karlina menggunakan metode Field Trip dan jenis penelitiannya menggunakan PTK, sedangkan yang penulis menggunakan metode preexperimental desains dengan jenis penelitian menggunakan eksperimen. Lalu penerapannya berbeda, saya menggunakan web yang telah disediakan oleh pihak sekolah tetapi cara pembelajarannya dengan online, dan hasil yang telah siswa kerjakan akan dikirim melalui Whatsapp. Sedangkan Karlina pembelajarannya secara langsung tatap muka dengan siswa-siswi sekolah.

Berdasarkan penjelasan diatas maka, dapat penulis simpulkan bahwa perbedaan yang dilakukan Karlina dengan penelitian penulis berada pada metode yang digunakan, dan jenis penelitiannya. Adapun proses penelitiannya yang membedakan penulis dengan penelitian Karlina adalahnya secara online, sedangkan Karlina dengan tatap muka atau offline. Dikarenakan keadaan saat ini sedang pandemic, makanya penulis berinisiatif untuk menggunakan media gambar sebagai wadah belajar siswa-siswi agar dapat menarik minat dalam belajar meskipun cara online.

\section{METODE PENELITIAN}

Pada penelitian ini peneliti menggunakan pendekatan kuantitatif karena data-data disajikan berupa angka dan dianalisis menggunakan bentuk statis. Menurut (Sugiyono, 2017) mengemukakan bahwa penelitian kuantitatif adalah metode penelitian yang berlandaskan pada filsafat positifisme, digunakan untuk meneliti pada populasi atau sampel tertentu, pengumpulan data menggunakan instrument penelitian, analisis data bersifat kuantitatif/statistic, dengan tujuan untuk menguji hipotesis yang telah ditetapkan.

Metode penelitian yang digunakan adalah metode pre-experimental desains. Menurut (Sugiyono, 2017) konsep metode penelitian eksperimen yaitu metode yang digunakan untuk mencari pengaruh perlakuan tertentu terhadap yang lain dalam kondisi yang terkendali. Adapun perlakuan media gambar yang diuji cobakan pada akhir tes atau disebut posttest. Jadi, keterampilan menulis teks prosedur akan diberikan pada awal tes (pretest) sebelum diberikan perlakuan, lalu tes keterampilan menulis teks prosedur selanjutnya diberikan setelah adanya perlaku (posttest).

Menurut (Sugiyono, 2017) populasi adalah wilayah generalisasi yang terdiri atas objek/ subjek yang mempunyai kualitas dan karakteristik tertentu yang ditetapkan oleh peneliti untuk dipelajari dan kemudian ditarik kesimpulannya. Adapun populasi yang digunakan dalam penelitian ini adalah kelas VII di Sekolah Menengah Pertama Negeri 3 Cikarang Timur. Berikut data populasi dari kelas VII SMP Negeri 3 Cikarang Timur.

Tabel 1. Populasi Siswa Kelas VII SMP Negeri 3 Cikarang Timur

\begin{tabular}{cc}
\hline Kelas & Jumlah \\
\hline 7.1 & 39 \\
\hline 7.2 & 38 \\
\hline 7.3 & 38 \\
\hline 7.4 & 38 \\
\hline 7.5 & 38 \\
\hline
\end{tabular}


1926 Keefektifan Penggunaan Media Gambar Seri dalam Pembelajaran Menulis Teks Prosedur pada Siswa Sekolah Menengah Pertama - Avillia Nuraenita, Wienike Dinar Pratiwi, Een Nurhasanah

DOI: https://doi.org/10.31004/edukatif.v3i4.1105

\begin{tabular}{cc}
\hline 7.6 & 38 \\
\hline 7.7 & 38 \\
\hline Total & $\mathbf{2 6 7}$ \\
\hline
\end{tabular}

Menurut (Sugiyono, 2017) sampel merupakan jumlah dan karakteristik yang dimiliki oleh populasi tersebut. Pemilihan sampel menggunakan Sampling Purposive, menurut (Sugiyono, 2017) adalah teknik penentuan sampel dengan pertimbangan tertentu. Maka berdasarkan hal tersebut peneliti disarankan oleh guru bidang studi yang bersangkutan untuk mengambil sampel pada kelas VII.1 dengan jumlah siswa 39.

Desain penelitian ini menggunakan one-group pretest-posttest design. Terdapat 1 kelas yang dipilih secara random (acak), yaitu $\mathrm{O} 1$ sebagai nilai pretest, variable $\mathrm{X}$ adalah sebuah pelakuan yang akan dilakukan pada $\mathrm{O} 2$ yaitu nilai posttest, dalam hal ini adalah media yang akan diterapkan pada siswa.

\begin{tabular}{ccc}
\hline $\mathrm{O}^{1}$ & $\mathrm{X}$ & $0^{2}$ \\
\hline & Sumber: (Sugiyono, 2017)
\end{tabular}

Teknik pengumpulan data pada penelitian ini menggunakan beberapa instrument yaitu instrument tes dan non tes. Berikut penjelasannya:

Instrumen tes pada penelitian ini digunakan peneliti sebagai teknik pengumpulan data, karena tujuan utama pada penelitian ini adalah untuk mendeskripsikan keefektifan media gambar dalam keterampilan menulis teks prosedur pada siswa kelas VII. Adapun instrumen yang digunakan berupa instrument tes (uraian) pada keterampilan awal dan keterampilan akhir. Tes berupa 5 soal uraian, berikut bentuk soalnya:

Tabel 2. Instrumen Tes

\begin{tabular}{l}
\hline \multicolumn{1}{c}{ SOAL TEKS PROSEDUR } \\
\hline Buatlah teks prosedur dari gambar di bawah ini \\
sesuai dengan struktur! (tujuan alat dan bahan, \\
langkah-langkah, dan penutup) \\
\hline
\end{tabular}

Selanjutnya, hasil dari menulis teks prosedur tentu harus diberikan penilaian. Dalam hal ini peneliti memiliki aspek penilaian untuk mengetahui hasil menulis siswa. Berikut aspek penilaiannya:

Tabel 3. Instrumen Penilaian

\begin{tabular}{|c|c|c|c|}
\hline No & $\begin{array}{c}\text { Aspek Penilaian } \\
\text { Indikator }\end{array}$ & Kriteria & Skor \\
\hline \multirow{5}{*}{1} & \multirow{5}{*}{ Tujuan } & Disampaikan dengan sangat jelas & 5 \\
\hline & & Disampaikan dengan jelas & 4 \\
\hline & & Disampaikan dengan cukup jelas & 3 \\
\hline & & Disampaikan dengan kurang jelas & 2 \\
\hline & & Disampaikan dengan tidak jelas & 1 \\
\hline \multirow{5}{*}{2} & \multirow{5}{*}{ Alat dan Bahan } & Disampaikan dengan sangat jelas & 5 \\
\hline & & Disampaikan dengan jelas & 4 \\
\hline & & Disampaikan dengan cukup jelas & 3 \\
\hline & & Disampaikan dengan kurang jelas & 2 \\
\hline & & Disampaikan dengan tidak jelas & 1 \\
\hline \multirow{5}{*}{3} & \multirow{5}{*}{ Langkah-langkah } & Disampaikan dengan sangat jelas & 5 \\
\hline & & Disampaikan dengan jelas & 4 \\
\hline & & Disampaikan dengan cukup jelas & 3 \\
\hline & & Disampaikan dengan kurang jelas & 2 \\
\hline & & Disampaikan dengan tidak jelas & 1 \\
\hline
\end{tabular}


1927 Keefektifan Penggunaan Media Gambar Seri dalam Pembelajaran Menulis Teks Prosedur pada Siswa Sekolah Menengah Pertama - Avillia Nuraenita, Wienike Dinar Pratiwi, Een Nurhasanah

DOI: https://doi.org/10.31004/edukatif.v3i4.1105

\begin{tabular}{|c|c|c|c|}
\hline \multirow{5}{*}{4} & \multirow{5}{*}{ Penutup } & Disampaikan dengan sangat jelas & 5 \\
\hline & & Disampaikan dengan jelas & 4 \\
\hline & & Disampaikan dengan cukup jelas & 3 \\
\hline & & Disampaikan dengan kurang jelas & 2 \\
\hline & & Disampaikan dengan tidak jelas & 1 \\
\hline
\end{tabular}

Tentu saja ini hanya ini gambaran dari bentukk soal dan aspek penilaian. Peneliti akan mengkonsultasikan kepada pihak yang lebih asli dalam bidangnya.

Selain instrumen tes, peneliti juga menambahkan instrument nontes berupa wawancara kepada guru bidang studi yang berkenaan dengan perkembangan siswa selama belajar, respon siswa, dan kendala yang dialami ketika pembelajaran. Karena penelitian ini berlangsung ketika pandemi, maka peneliti menyesuaikan pertanyaan ketika wawancara berlangsung.

Teknik analisis data merupakan cara mengolah data menjadi informasi. Pengambilan data dalam penelitian ini dengan memberikan sebuah tes yang berupa soal uraian. Tes keterampilan awal dilakukan sebelum diberikan perlakuan, sedangkan tes keterampilan akhir dilakukan setelah diberikan perlakuan. Data hasil keterampilan awal digunakan peneliti untuk melihat keterampilan awal menulis tek prosedur, dan keterampilan akhir yang akan digunakan untuk melihat peningkatan nilai setelah diberikan media gambar.

Teknik analisis data yang digunakan dalam penelitian ini adalah teknik analisis statistic destriptif. Menurut (Sugiyono, 2017) statistic deskriptif adalah statistik yang digunakan untuk menganalisis data dengan cara mendeskripsikan atau menggambarkan data yang telah terkumpul sebagaimana adanya tanpa bermaksud membuat kesimpulan yang berlaku untuk umum dan generalisasi. Jadi, analisis data statistic digunakan untuk menghitung nilai hasil rata-rata, dan data statistik yang diperoleh pada pretest (sebelum treatmen) dan posttest (sesudah treatmen). Data yang pertama kali dianalisis adalah tes awal keterampilan menulis teks prosedur atau pretest. Hal ini digunakan untuk melihat keterampilan awal menulis teks prosedur. Lalu tes selanjutnya diberikan setelah adanya perlakuan, agar dapat membandingkan hasil keterampilan menulis teks prosedur sebelum diberikan perlakuan dan sesudah diberikan perlakuan.

Tabel 4. Aspek Penilaian

\begin{tabular}{ccc}
\hline No & Aspek Yang Dinilai & Skor \\
\hline 1. & Tujuan & 5 \\
\hline 2. & Alat dan Bahan & 5 \\
\hline 3. & Langkah-langkah & 5 \\
\hline 4. & Penutup & 5 \\
\hline & Jumlah Skor & $\mathbf{2 0}$ \\
\hline
\end{tabular}

Menghitung rata-rata skor siswa dengan menggunakan rumus:

$$
\begin{aligned}
& \boldsymbol{X} \boldsymbol{i}=\frac{\boldsymbol{\Sigma X}}{\mathbf{N}} \\
& \text { Sumber: (Burhan Nurgiyantoro, 2016) } \\
& \mathrm{Xi}=\text { Rata-rata skor } \quad \mathrm{N}=\text { Jumlah keseluruhan } \\
& \Sigma \mathrm{X}=\text { Jumlah keseluruhan } \mathrm{f}(\mathrm{x})
\end{aligned}
$$

Pedoman untuk Memberikan Interpretasi terhadap Data Sampel:

Tabel 5. Interval Nilai

\begin{tabular}{ccc}
\hline No. & Interval Nilai & Keterangan \\
\hline 1. & $85-100$ & Baik Sekali \\
\hline
\end{tabular}


1928 Keefektifan Penggunaan Media Gambar Seri dalam Pembelajaran Menulis Teks Prosedur pada Siswa Sekolah Menengah Pertama - Avillia Nuraenita, Wienike Dinar Pratiwi, Een Nurhasanah

DOI: https://doi.org/10.31004/edukatif.v3i4.1105

\begin{tabular}{ccc}
\hline 2. & $69-84$ & Baik \\
\hline 3. & $53-68$ & Cukup \\
\hline 4. & $37-52$ & Kurang \\
\hline 5. & $21-36$ & Kurang Sekali \\
\hline & \multicolumn{2}{c}{ Sumber: (Burhan Nurgiyantoro, 2016) }
\end{tabular}

Membuat Tabel Klasifikasi Kemampuan Siswa:

Tabel 6. Klasifikasi Kemampuan Siswa

\begin{tabular}{cccc}
\hline No. & Pemerolehan Nilai & Frekuensi & Persentase \\
\hline 1. & $75-100$ & $\ldots$ & $\ldots$ \\
\hline 2. & $0-74$ & $\ldots$ & $\ldots$ \\
\hline
\end{tabular}

Kemampuan siswa dapat dikatakan memadai apabila persentase siswa memperoleh 75 ke atas adalah $75 \%$ atau lebih. Jika belum memadai maka persentase siswa memperoleh nilai 75 kurang dari $75 \%$.

\section{HASIL DAN PEMBAHASAN PENELITIAN}

Pada bab ini, peneliti mendeskripsikan secara rinci mengenai kemampuan menulis teks prosedur sesuai dengan strukturnya pada siswa kelas VII Sekolah Menengah Pertama Negeri 3 Cikarang Timur. Jenis penelitian ini adalah kuantitatif. Hasil kuantitatif yang dimaksud dalam penelitian ini adalah hasil yang dinyatakan dalam bentuk angka untuk mengetahui kemampuan rata-rata siswa dalam menulis teks prosedur ditinjau dari segi struktur (tujuan, alat dan bahan, langkah-langkah dan penutup). Berikut rinciannya:

\section{Kemampuan Menulis Teks Prosedur Pada Aspek Tujuan Siswa Kelas VII Sekolah Menengah Pertama Negeri 3 Cikarang Timur}

Tujuan merupakan pengantar yang menjelaskan tujuan dari prosedur. Aspek penilaian dalam aspek tujuan terdiri atas 5 kriteria penilaian yakni, disampaikan dengan sangat jelas dengan skor 5 , disampaikan dengan jelas dengan skor 4, disampaikan dengan cukup jelas dengan skor 3, disampaikan dengan kurang jelas dengan skor 2, dan disampaikan dengan tidak jelas dengan skor 1.

Tabel 7 (Pretest) Distribusi Kriteria Kemampuan Menulis Teks Prosedur Pada Aspek Tujuan Siswa Kelas VII Sekolah Menengah Pertama Negeri 3 Cikarang Timur

\begin{tabular}{clccc}
\hline No. & $\begin{array}{l}\text { Kriteria Penilaian } \\
\text { Aspek Tujuan (X) }\end{array}$ & Frekuensi (F) & (f)X & Persentase \\
\hline 1. & $\begin{array}{l}\text { Disampaikan dengan } \\
\text { sangat jelas }\end{array}$ & 0 & 0 & $0 \%$ \\
\hline 2. & $\begin{array}{l}\text { Disampaikan dengan } \\
\text { jelas }\end{array}$ & 4 & 16 & $15 \%$ \\
\hline 3. & $\begin{array}{l}\text { Disampaikan dengan } \\
\text { cukup jelas }\end{array}$ & 24 & 72 & $66 \%$ \\
\hline 4. & $\begin{array}{l}\text { Disampaikan dengan } \\
\text { kurang jelas }\end{array}$ & 10 & 20 & $18 \%$ \\
\hline 5. & $\begin{array}{l}\text { Disampaikan dengan } \\
\text { tidak jelas }\end{array}$ & 1 & 1 & $1 \%$ \\
\hline & Jumlah & $\mathbf{N = 3 9}$ & $\mathbf{\Sigma ( f ) X = 1 0 9}$ & $\mathbf{1 0 0 \%}$ \\
\hline
\end{tabular}

Dari tabel kriteria penilaian pada data pretest dengan aspek tujuan diperoleh gambaran bahwa, siswa yang dapat menyampaikan dengan jelas sebanyak 4 orang, siswa yang dapat menyampaikan dengan cukup jelas sebanyak 24 orang, siswa yang menyampaikan dengan kurang jelas sebanyak 10 orang, dan siswa yang 
1929 Keefektifan Penggunaan Media Gambar Seri dalam Pembelajaran Menulis Teks Prosedur pada Siswa Sekolah Menengah Pertama - Avillia Nuraenita, Wienike Dinar Pratiwi, Een Nurhasanah

DOI: https://doi.org/10.31004/edukatif.v3i4.1105

menyampaikannya dengan tidak jelas sebanyak 1 orang. Dengan demikian siswa yang mampu menulis teks prosedur sebanyak 28 orang (72\%) persentase ini lebih kecil dari standar tolak ukur kemampuan siswa yaitu $75 \%$, sehingga pada aspek tujuan (pretest) siswa dikatakan belum mampu.

Tabel 8 (Posttest) Distribusi Kriteria Kemampuan Menulis Teks Prosedur Pada Aspek Tujuan Siswa Kelas VII Sekolah Menengah Pertama Negeri 3 Cikarang Timur

\begin{tabular}{clccc}
\hline No. & $\begin{array}{l}\text { Kriteria Penilaian Aspek } \\
\text { Tujuan (X) }\end{array}$ & Frekuensi (F) & $(\mathbf{f}) \mathbf{X}$ & Persentase \\
\hline 1. & $\begin{array}{l}\text { Disampaikan dengan sangat } \\
\text { jelas }\end{array}$ & 1 & 5 & $4 \%$ \\
\hline 2. & Disampaikan dengan jelas & 13 & 52 & $42 \%$ \\
\hline 3. & $\begin{array}{l}\text { Disampaikan dengan cukup } \\
\text { jelas }\end{array}$ & 18 & 54 & $43 \%$ \\
\hline 4. & $\begin{array}{l}\text { Disampaikan dengan } \\
\text { kurang jelas }\end{array}$ & 6 & 12 & $10 \%$ \\
\hline 5. & $\begin{array}{l}\text { Disampaikan dengan tidak } \\
\text { jelas }\end{array}$ & 1 & 1 & $1 \%$ \\
\hline & \multicolumn{1}{c}{ Jumlah } & $\mathbf{N = 3 9}$ & $\mathbf{\Sigma ( f ) X = 1 2 4}$ & $\mathbf{1 0 0 \%}$
\end{tabular}

Dari table kriteria penilaian pada data posttest dengan aspek tujuan diperoleh gambaran bahwa, siswa yang dapat menyampaikan dengan sangat jelas sebanyak 1 orang, siswa yang dapat menyampaikan dengan jelas sebanyak 13 orang, siswa yang dapat menyampaikan dengan cukup jelas sebanyak 18 orang, siswa yang menyampaikan dengan kurang jelas sebanyak 6 orang, dan siswa yang menyampaikan dengan tidak jelas sebanyak 1 orang. Dengan demikian siswa yang mampu menulis teks prosedur sebanyak 32 orang (82\%) persentase ini lebih kecil dari standar tolak ukur kemampuan siswa yaitu 75\%, sehingga pada aspek tujuan (posttest) siswa dikatakan belum mampu.

\section{Kemampuan Menulis Teks Prosedur pada Aspek Alat dan Bahan Siswa Kelas VII Sekolah Menengah Pertama Negeri 3 Cikarang Timur}

Alat dan bahan merupakan rincian mengenai bahan dan peralatan yang dibutuhkan dalam aktivitas yang akan dilakukan. Aspek penilaian dalam aspek tujuan terdiri atas 5 kriteria penilaian yakni, disampaikan dengan sangat jelas dengan skor 5, disampaikan dengan jelas dengan skor 4, disampaikan dengan cukup jelas dengan skor 3, disampaikan dengan kurang jelas dengan skor 2, dan disampaikan dengan tidak jelas dengan skor 1 .

Tabel 9 (pretest) Distribusi Kriteria Kemampuan Menulis Teks Prosedur Pada Aspek Alat dan Bahan Siswa Kelas VII Sekolah Menengah Pertama Negeri 3 Cikarang Timur

\begin{tabular}{clccc}
\hline No. & $\begin{array}{l}\text { Kriteria Penilaian } \\
\text { Aspek Tujuan (X) }\end{array}$ & Frekuensi (F) & (f)X & Persentase \\
\hline 1. & $\begin{array}{l}\text { Disampaikan dengan } \\
\text { sangat jelas }\end{array}$ & 0 & 0 & $0 \%$ \\
\hline 2. & $\begin{array}{l}\text { Disampaikan dengan } \\
\text { jelas }\end{array}$ & 8 & 32 & $26 \%$ \\
\hline 3. & $\begin{array}{l}\text { Disampaikan dengan } \\
\text { cukup jelas }\end{array}$ & 29 & 87 & $72 \%$ \\
\hline 4. & $\begin{array}{l}\text { Disampaikan dengan } \\
\text { kurang jelas }\end{array}$ & 0 & 0 & $0 \%$ \\
\hline 5. & $\begin{array}{l}\text { Disampaikan dengan } \\
\text { tidak jelas }\end{array}$ & 2 & 2 & $2 \%$ \\
\hline & $\quad$ Jumlah & $\mathbf{N = 3 9}$ & $\mathbf{\Sigma ( f ) X = 1 2 1}$ & $\mathbf{1 0 0 \%}$ \\
\hline
\end{tabular}


1930 Keefektifan Penggunaan Media Gambar Seri dalam Pembelajaran Menulis Teks Prosedur pada Siswa Sekolah Menengah Pertama - Avillia Nuraenita, Wienike Dinar Pratiwi, Een Nurhasanah

DOI: https://doi.org/10.31004/edukatif.v3i4.1105

Dari tabel kriteria penilaian pada data pretest dengan aspek alat dan bahan diperoleh gambaran bahwa, siswa yang dapat menyampaikan dengan jelas sebanyak 8 orang, siswa yang dapat menyampaikan dengan cukup jelas sebanyak 29 orang, dan siswa yang menyampaikannya dengan tidak jelas sebanyak 2 orang. Dengan demikian siswa yang mampu menulis teks prosedur sebanyak 37 orang (95\%) persentase ini lebih besar dari standar tolak ukur kemampuan siswa yaitu 75\%, sehingga pada aspek alat dan bahan (pretest) siswa dikatakan mampu.

Tabel 10 (posttest) Distribusi Kriteria Kemampuan Menulis Teks Prosedur Pada Aspek Alat dan Bahan Siswa Kelas VII Sekolah Menengah Pertama Negeri 3 Cikarang Timur

\begin{tabular}{clccc}
\hline No. & $\begin{array}{c}\text { Kriteria Penilaian } \\
\text { Aspek Tujuan (X) }\end{array}$ & Frekuensi (F) & $(\mathbf{f}) \mathbf{X}$ & Persentase \\
\hline 1. & $\begin{array}{l}\text { Disampaikan dengan } \\
\text { sangat jelas }\end{array}$ & 0 & 0 & $0 \%$ \\
\hline 2. & Disampaikan dengan jelas & 21 & 84 & $62 \%$ \\
\hline 3. & $\begin{array}{l}\text { Disampaikan dengan } \\
\text { cukup jelas }\end{array}$ & 17 & 51 & $37 \%$ \\
\hline 4. & $\begin{array}{l}\text { Disampaikan dengan } \\
\text { kurang jelas }\end{array}$ & 0 & 0 & $0 \%$ \\
\hline 5. & $\begin{array}{l}\text { Disampaikan dengan } \\
\text { tidak jelas }\end{array}$ & 1 & 1 & $1 \%$ \\
\hline & $\quad$ Jumlah & $\mathbf{N}=\mathbf{3 9}$ & $\mathbf{\Sigma ( f ) X = 1 3 6}$ & $\mathbf{1 0 0 \%}$ \\
\hline
\end{tabular}

Dari tabel kriteria penilaian pada data posttest dengan aspek alat dan bahan diperoleh gambaran sebanyak, siswa yang dapat menyampaikan dengan jelas sebanyak 21 orang, siswa yang dapat menyampaikan dengan cukup jelas sebanyak 17 orang, dan siswa yang menyampaikan dengan tidak jelas sebanyak 1 orang. Dengan demikian siswa yang mampu menulis teks prosedur sebanyak 38 orang (97\%) persentase ini lebih besar dari standar tolak ukur kemampuan siswa yaitu 75\%, sehingga pada aspek alat dan bahan (posttest) siswa dikatakan mampu.

\section{Kemampuan Menulis Teks Prosedur Pada Aspek Langkah-langkah Siswa Kelas VII Sekolah Menengah Pertama Negeri 3 Cikarang Timur}

Langkah-langkah merupakan tahapan proses teks prosedur yang dijelaskan secara rinci dan berurutan dari awal hingga akhir. Aspek penilaian dalam aspek tujuan terdiri atas 5 kriteria penilaian yakni, disampaikan dengan sangat jelas dengan skor 5, disampaikan dengan jelas dengan skor 4, disampaikan dengan cukup jelas dengan skor 3, disampaikan dengan kurang jelas dengan skor 2, dan disampaikan dengan tidak jelas dengan skor 1 .

Tabel 11 (pretest) Kemampuan Menulis Teks Prosedur Pada Aspek Langkah-langkah Siswa Kelas VII Sekolah Menengah Pertama Negeri 3 Cikarang Timur

\begin{tabular}{clccc}
\hline No. & $\begin{array}{c}\text { Kriteria Penilaian } \\
\text { Aspek Tujuan (X) }\end{array}$ & Frekuensi (F) & (f)X & Persentase \\
\hline 1. & $\begin{array}{l}\text { Disampaikan dengan } \\
\text { sangat jelas }\end{array}$ & 0 & 0 & $0 \%$ \\
\hline 2. & Disampaikan dengan jelas & 6 & 24 & $20 \%$ \\
\hline 3. & $\begin{array}{l}\text { Disampaikan dengan } \\
\text { cukup jelas }\end{array}$ & 30 & 90 & $75 \%$ \\
\hline 4. & $\begin{array}{l}\text { Disampaikan dengan } \\
\text { kurang jelas }\end{array}$ & 3 & 6 & $5 \%$ \\
\hline
\end{tabular}


1931 Keefektifan Penggunaan Media Gambar Seri dalam Pembelajaran Menulis Teks Prosedur pada Siswa Sekolah Menengah Pertama - Avillia Nuraenita, Wienike Dinar Pratiwi, Een Nurhasanah

DOI: https://doi.org/10.31004/edukatif.v3i4.1105

\begin{tabular}{cccc}
\hline 5. $\begin{array}{l}\text { Disampaikan dengan } \\
\text { tidak jelas }\end{array}$ & 0 & 0 & $0 \%$ \\
\hline Jumlah & $\mathbf{N}=\mathbf{3 9}$ & $\mathbf{\Sigma ( f )} \mathbf{X}=\mathbf{1 2 0}$ & $\mathbf{1 0 0} \%$ \\
\hline
\end{tabular}

Dari tabel kriteria penilaian pada data pretest dengan aspek langkah-langkah diperoleh gambaran bahwa, siswa yang dapat menyampaikan dengan jelas sebanyak 6 orang, siswa yang dapat menyampaikan dengan cukup jelas sebanyak 30 orang, dan siswa yang menyampaikan dengan kurang jelas sebanyak 3 orang. Dengan demikian siswa yang mampu menulis teks prosedur sebanyak 36 orang (92\%) persentase ini lebih besar dari standar tolak ukur kemampuan siswa yaitu 75\%, sehingga pada aspek langkah-langkah (pretest) siswa dikatakan mampu.

Tabel 12 (posttest) Kemampuan Menulis Teks Prosedur Pada Aspek Langkah-langkah Siswa Kelas VII Sekolah Menengah Pertama Negeri 3 Cikarang Timur

\begin{tabular}{clccc}
\hline No. & $\begin{array}{l}\text { Kriteria Penilaian } \\
\text { Aspek Tujuan (X) }\end{array}$ & Frekuensi (F) & $(\mathbf{f}) \mathbf{X}$ & Persentase \\
\hline 1. & $\begin{array}{l}\text { Disampaikan dengan } \\
\text { sangat jelas }\end{array}$ & 34 & 170 & $91 \%$ \\
\hline 2. & Disampaikan dengan jelas & 2 & 8 & $4 \%$ \\
\hline 3. & $\begin{array}{l}\text { Disampaikan dengan } \\
\text { cukup jelas }\end{array}$ & 3 & 9 & $5 \%$ \\
\hline 4. & $\begin{array}{l}\text { Disampaikan dengan } \\
\text { kurang jelas }\end{array}$ & 0 & 0 & $0 \%$ \\
\hline 5. & $\begin{array}{l}\text { Disampaikan dengan } \\
\text { tidak jelas }\end{array}$ & 0 & 0 & $0 \%$ \\
\hline & Jumlah & $\mathbf{N = 3 9}$ & $\mathbf{\Sigma ( f ) X = 1 8 7}$ & $\mathbf{1 0 0} \%$ \\
\hline
\end{tabular}

Dari tabel kriteria penilaian pada data pretest dengan aspek langkah-langkah diperoleh gambaran bahwa, siswa yang dapat menyampaikan dengan sangat jelas sebanyak 34 orang, siswa yang dapat menyampaikan dengan jelas sebanyak 2 orang, dan siswa yang dapat menyampaikan dengan cukup jelas sebanyak 3 orang. Dengan demikian siswa yang mampu menulis teks prosedur sebanyak 39 orang (100\%) persentase ini lebih besar dari standar tolak ukur kemampuan siswa yaitu 75\%, sehingga pada aspek langkahlangkah (posttest) siswa dikatakan mampu.

\section{Kemampuan Menulis Teks Prosedur Pada Aspek Penutup Siswa Kelas VII Sekolah Menengah Pertama Negeri 3 Cikarang Timur}

Penutup diisi dengan kalimat-kalimat yang seperlunya, tidak berupa kesimpulan yang hanya terdiri atas dua kalimat. Seolah-olah kalimat tersebut hanya berfungsi sebagai penanda bahwa teks itu sudah selesai. Aspek penilaian dalam aspek tujuan terdiri atas 5 kriteria penilaian yakni, disampaikan dengan sangat jelas dengan skor 5, disampaikan dengan jelas dengan skor 4, disampaikan dengan cukup jelas dengan skor 3, disampaikan dengan kurang jelas dengan skor 2, dan disampaikan dengan tidak jelas dengan skor 1.

Tabel 13 (pretest) Kemampuan Menulis Teks Prosedur Pada Aspek Penutup Siswa Kelas VII Sekolah Menengah Pertama Negeri 3 Cikarang Timur

\begin{tabular}{clccc}
\hline No. & $\begin{array}{c}\text { Kriteria Penilaian } \\
\text { Aspek Tujuan (X) }\end{array}$ & Frekuensi (F) & (f)X & Persentase \\
\hline 1. & $\begin{array}{l}\text { Disampaikan dengan } \\
\text { sangat jelas }\end{array}$ & 0 & 0 & $0 \%$ \\
\hline 2. & Disampaikan dengan jelas & 9 & 36 & $31 \%$ \\
\hline 3. & Disampaikan dengan & 21 & 63 & $54 \%$ \\
\hline
\end{tabular}


1932 Keefektifan Penggunaan Media Gambar Seri dalam Pembelajaran Menulis Teks Prosedur pada Siswa Sekolah Menengah Pertama - Avillia Nuraenita, Wienike Dinar Pratiwi, Een Nurhasanah

DOI: https://doi.org/10.31004/edukatif.v3i4.1105

\begin{tabular}{llccc}
\hline & cukup jelas & & & \\
\hline 4. & $\begin{array}{l}\text { Disampaikan dengan } \\
\text { kurang jelas }\end{array}$ & 9 & 18 & $15 \%$ \\
\hline 5. & $\begin{array}{l}\text { Disampaikan dengan } \\
\text { tidak jelas }\end{array}$ & 0 & 0 & $0 \%$ \\
\hline & Jumlah & $\mathbf{N}=\mathbf{3 9}$ & $\mathbf{\Sigma ( f ) X = 1 1 7}$ & $\mathbf{1 0 0} \%$ \\
\hline
\end{tabular}

Dari tabel kriteria penilaian pada data pretest dengan aspek langkah-langkah diperoleh gambaran bahwa, siswa yang dapat menyampaikan dengan jelas sebanyak 9 orang, siswa yang dapat menyampaikan dengan cukup jelas sebanyak 21 orang, dan siswa yang menyampaikan dengan kurang jelas sebanyak 9 orang. Dengan demikian siswa yang mampu menulis teks prosedur sebanyak 30 orang (77\%) persentase ini lebih besar dari standar tolak ukur kemampuan siswa yaitu 75\%, sehingga pada aspek penutup (pretest) siswa dikatakan mampu.

Tabel 14 (posttest) Kemampuan Menulis Teks Prosedur Pada Aspek Penutup Siswa Kelas VII Sekolah Menengah Pertama Negeri 3 Cikarang Timur

\begin{tabular}{clccc}
\hline No. & $\begin{array}{c}\text { Kriteria Penilaian } \\
\text { Aspek Tujuan (X) }\end{array}$ & Frekuensi (F) & $(\mathbf{f}) \mathbf{X}$ & Persentase \\
\hline 1. & $\begin{array}{l}\text { Disampaikan dengan } \\
\text { sangat jelas }\end{array}$ & 2 & 10 & $7 \%$ \\
\hline 2. & Disampaikan dengan jelas & 20 & 80 & $58 \%$ \\
\hline 3. & $\begin{array}{l}\text { Disampaikan dengan } \\
\text { cukup jelas }\end{array}$ & 15 & 45 & $33 \%$ \\
\hline 4. & $\begin{array}{l}\text { Disampaikan dengan } \\
\text { kurang jelas }\end{array}$ & 1 & 2 & $1 \%$ \\
\hline 5. & $\begin{array}{l}\text { Disampaikan dengan } \\
\text { tidak jelas }\end{array}$ & 1 & 1 & $1 \%$ \\
\hline & Jumlah & $\mathbf{N = 3 9}$ & $\mathbf{\Sigma ( f ) X = 1 3 8}$ & $\mathbf{1 0 0 \%}$ \\
\hline
\end{tabular}

Dari tabel kriteria penilaian pada data pretest dengan aspek langkah-langkah diperoleh gambaran bahwa, siswa yang dapat menyampaikan dengan sangat jelas sebanyak 2 orang, siswa yang dapat menyampaikan dengan jelas sebanyak 20 orang, siswa yang dapat menyampaikan dengan cukup jelas sebanyak 15 orang, siswa yang menyampaikan dengan kurang jelas sebanyak 1 orang, dan siswa yang menyampaikan dengan tidak jelas sebanyak 1 orang. Dengan demikian siswa yang mampu menulis teks prosedur sebanyak 37 orang (95\%) persentase ini lebih besar dari standar tolak ukur kemampuan siswa yaitu $75 \%$, sehingga pada aspek penutup (posttest) siswa dikatakan mampu.

Penelitian ini bertujuan untuk mendeskripsikan kemampuan menulis teks prosedur dengan tanpa media dan dengan penerapan media pada siswa Sekolah Menengah Pertama Negeri 3 Cikarang Timur ditinjau dari segi struktur teks prosedur. Berdasarkan penyajian hasil data, dapat diuraikan temuan yang diperoleh dalam penelitian ini bahwa media pembelajaran mempengaruhi kemampuan menulis pada siswa kelas VII.1 Sekolah Menengah Pertama Negeri 3 Cikarang Timur dalam menulis teks prosedur dari segi strukturnya. Berdasarkan hasil pengolahan data, tampak bahwa hasil tes kemampuan siswa kelas VII.1 Sekolah Menengah Pertama Negeri 3 Cikarang Timur dalam keterampilan menulis teks prosedur berada pada kategori baik dengan nilai rata-rata 75. Adapun hasil perbandingan antara tes pertama (pretest) dengan tes kedua (posttest). Pada tes pertama memiliki hasil rata-rata 59,60 dengan kategori cukup. Sedangkan pada tes kedua memiliki hasil ratarata 75 dengan kategori baik seperti yang sudah dideskripsikan di atas. 
1933 Keefektifan Penggunaan Media Gambar Seri dalam Pembelajaran Menulis Teks Prosedur pada Siswa Sekolah Menengah Pertama - Avillia Nuraenita, Wienike Dinar Pratiwi, Een Nurhasanah

DOI: https://doi.org/10.31004/edukatif.v3i4.1105

Menurut data tersebut, media pembelajaran dapat mempengaruhi proses belajar bagi siswa. Jadi, media pembelajaran yang telah penulis buat untuk membantu keterampilan menulis siswa dapat dikatakan efektif karena adanya sebuah perbandingan dari hasil keterampilan menulis siswa.

1. Kemampuan Menulis Teks Prosedur Pada Aspek Tujuan Siswa Kelas VII Sekolah Menengah Pertama Negeri 3 Cikarang Timur

Tujuan merupakan pengantar yang menjelaskan tujuan dari prosedur. Hasil analisis data menunjukkan bahwa hasil menulis teks prosedur siswa dapat dikatakan mampu dengan persentase $82 \%$ dari keseluruhan jumlah siswa.

2. Kemampuan Menulis Teks Prosedur Pada Aspek Alat dan Bahan Siswa Kelas VII Sekolah Menengah Pertama Negeri 3 Cikarang Timur

Alat dan bahan merupakan rincian mengenai bahan dan peralatan yang dibutuhkan dalam aktivitas yang akan dilakukan. Hasil analisis data menunjukkan bahwa hasil menulis teks prosedur siswa dapat dikatakan mampu dengan persentase $97 \%$ dari keseluruhan jumlah siswa.

3. Kemampuan Menulis Teks Prosedur Pada Aspek Langkah-langkah Siswa Kelas VII Sekolah Menengah Pertama Negeri 3 Cikarang Timur

Langkah-langkah merupakan tahapan proses teks prosedur yang dijelaskan secara rinci dan berurutan dari awal hingga akhir. Hasil analisis data menunjukkan bahwa hasil menulis teks prosedur siswa dapat dikatakan mampu dengan persentase $100 \%$ dari keseluruhan jumlah siswa.

4. Kemampuan Menulis Teks Prosedur Pada Aspek Penutup Siswa Kelas VII Sekolah Menengah Pertama Negeri 3 Cikarang Timur

Penutup dapat diisi menggunakan kalimat-kalimat yang sekadarnya, tidak berupa kesimpulan yang hanya terdiri atas dua kalimat. Hasil analisis data menunjukkan bahwa hasil menulis teks prosedur siswa dapat dikatakan mampu dengan persentase $95 \%$ dari keseluruhan jumlah siswa.

Berdasarkan hasil pada penelitian sebelumnya mendapatkan hasil bahwa metode yang digunakan mendapatkan aktivitas yang meningkat bagi siswa dalam pembelajaran B.Indonesia pada materi teks prosedur, dapat meningkatkan keterampilan menulis dengan hasil rata-rata $65,62 \%$ pada siklus ke I dan $87,87 \%$ pada siklus ke II. Sedangkan hasil yang penulis dapat dalam keteampilan menulis dengan tanpa media dan dengan media mendapatkan hasil yang cukup meningkat dari tiap aspek yang penulis gunakan. Pada aspek tujuan tes ke I dengan hasil rata-rata $72 \%$ pada tes ke II dengan rata-rata $82 \%$. Pada aspek alat dan bahan tes ke I dengan hasil rata-rata 95\% pada tes ke II dengan rata-rata 97\%. Pada aspek langkah-langkah tes ke I dengan hasil rata-rata $92 \%$ pada tes ke II dengan rata-rata $100 \%$. Pada aspek penutup tes ke I dengan hasil rata-rata $77 \%$ pada tes ke II dengan rata-rata 95\%. Dalam proses pembelajaran keterampilan menulis, penulis sangat setuju menggunakan metode dan media yang cocok untuk meningkatkan minat belajar siswa baik secara daring atau luring. Karena tujuan dari pendidikan itu sendiri ialah untuk mengembangkan kemampuan, membentuk karakter yang baik dan bijak, mencerdaskan kehidupan bangsa agar peserta didik dapat menjadi manusia yang sehat, berakal, dan beriman.

\section{KESIMPULAN}

Berdasarkan hasil analisis data dan pembahasan, dapat peneliti simpulkan bahwa penggunaan media gambar sangat berpengaruh terhadap kemampuan menulis teks prosedur pada siswa kelas VII Sekolah Menengah Pertama Negeri 3 Cikarang Timur. Kemampuan dalam menulis teks prosedur ditinjau dari segi struktur (tujuan, alat dan bahan, langkah-langkah, dan penutup) dapat dikatakan sudah memadai. Adapun hasil perbandingan antara tes pertama (pretest) dengan tes kedua (posttest). Pada tes pertama memiliki hasil ratarata 59,60 dengan kategori cukup. Sedangkan pada tes kedua memiliki hasil rata-rata 75 dengan kategori baik seperti yang sudah dideskripsikan di atas. Dengan demikian, dapat disimpulkan bahwa keefektifan media 
1934 Keefektifan Penggunaan Media Gambar Seri dalam Pembelajaran Menulis Teks Prosedur pada Siswa Sekolah Menengah Pertama - Avillia Nuraenita, Wienike Dinar Pratiwi, Een Nurhasanah

DOI: https://doi.org/10.31004/edukatif.v3i4.1105

gambar dalam keterampilan menulis teks prosedur dikategorikan sudah memadai atau baik. Hal ini dapat dibuktikan dengan persentase siswa yang diperoleh nilai di atas 75 sebesar $69 \%$ mendekati kriteria yaitu $75 \%$.

\section{UCAPAN TERIMA KASIH}

Penulis menyampaikan terima kasih sebesar-besarnya kepada dosen pembimbing yang telah sabar membimbing saya, lalu pihak sekolah SMP Negeri 3 Cikarang Timur, kepada keluarga khususnya kedua orang tua yang selalu memberikan semangat serta doa sehingga saya dapat menyelesaikan penelitian ini, dan terakhir kepada teman-teman. Penulis berharap semoga penelitian ini dapat bermanfaat bagi semua pihak yang membacanya. Penulis akhiri dengan mengucapkan terima kasih.

\section{DAFTAR PUSTAKA}

Anselmus, T. J. (2016). Teori Dan Filsafat Pendidikan (Ke-1). Gunung Samudera.

Argiandini, S. R. (2019). Keterampilan Menulis Resensi. INA-Rxiv Papers, 17. Https://Doi.Org/10.31227/Osf.Io/U26dz

Budiyono, H. (2010). Menulis Biografi: Jadikan Hidup Anda Lebih Bermakna! : Kiat Ramadhan K.H. Menulis Biografi Yang Memikat Dan Menyejarah.

Burhan Nurgiyantoro. (2016). Penilaian Pembelajaran Bahasa Berbasis Kompetensi (Ke-7). BPFEYogyakarta.

Cepy, R. (2012). Media Pembelajaran (Ke-2). Kemenag Ri.

Dalman .H. (2016). Keterampilan Menulis - Rajawali Pers - Google Books. Pt. Raja Grafindo Persada, Depok. Https://Www.Google.Co.Id/Books/Edition/Keterampilan_Menulis_Rajawali_Pers/3-

Cdeaaaqbaj?HI=Id\&Gbpv=1\&Dq=Keterampilan+Menulis \&Printsec=Frontcover

Dewi Ika Fitryana. (2011). Peningkatan Keterampilan Menulis Cerpen Melalui Media Berita Dengan Metode Latihan Terbimbing Pada Siswa Kelas X.3 Sma Negeri 1 Rembang Purbalingga. 66(July), 37-39. Https://Core.Ac.Uk/Download/Pdf/11059615.Pdf

Gereda Agustinus. (2020). Keterampilan Berbahasa Indonesia (Pratiwi Suci Anggia (Ed.); Ke-1). Edu Publisher.

H. Chomaidi \& Salamah. (2018). Filsafat Pendidikan - Google Books. Pt. Grasindo, Jakarta. Https://Www.Google.Co.Id/Books/Edition/Filsafat_Pendidikan/Ffpddwaaqbaj?Hl=Id\&Gbpv=1\&Dq=Fil safat+Pendidikan\&Printsec $=$ Frontcover

Haryanti, E. D. W. I. (2010). Melalui Media Gambar Seri Pada Siswa Kelas I Sd Negeri 02 Mojowetan , Kecamatan Banjarejo , Kabupaten Blora ,. UNS-FKIP Jur. Pendidikan Guru Sekolah Dasar-X.71086672010, 117.

Hendra, F. (2018). Peran Organisasi Mahasiswa Dalam Meningkatkan Mutu Pembelajaran Keterampilan Berbahasa Arab. Arabiyat: Jurnal Pendidikan Bahasa Arab Dan Kebahasaaraban, 5(1), 103-120. Https://Doi.Org/10.15408/A.V5i1.7480

Muhammad Anwar. (2015). Filsafat Pendidkan. Pt. Aditya Andrebina Agung, Jakarta.

Munirah. (2015). Pengembangan Keterampilan Menulis Paragraf - Munirah - Google Buku. Deepublish (Grup Penerbit CV Budi Utama), Yogyakarta. Https://Books.Google.Co.Id/Books?Id=Kosydwaaqbaj\&Printsec=Frontcover\&Dq=Keterampilan+Menul is $\& \mathrm{Hl}=\mathrm{Id} \&$ Newbks $=1 \& N e w b k s \_$Redir $=0 \& \mathrm{Sa}=\mathrm{X} \&$ Redir_Esc $=\mathrm{Y} \# \mathrm{~V}=$ Onepage $\& \mathrm{Q}=$ Keterampilan Menulis\&F=False

Mustofa Abi Hamid, Dkk. (2020). Media Pembelajaran - Google Books. Yayasan Kita Menulis. 
1935 Keefektifan Penggunaan Media Gambar Seri dalam Pembelajaran Menulis Teks Prosedur pada Siswa Sekolah Menengah Pertama - Avillia Nuraenita, Wienike Dinar Pratiwi, Een Nurhasanah DOI: https://doi.org/10.31004/edukatif.v3i4.1105

Https://Www.Google.Co.Id/Books/Edition/Media_Pembelajaran/Nplzdwaaqbaj?Hl=Id\&Gbpv=1\&Dq= Media+Pembelajaran\&Printsec $=$ Frontcover

Sholeh, K., \& Afriani, S. (2016). JPSE: Teknik Mind Mapping Sebagai Upaya Untuk Meningkatkan Keterampilan Menulis Cerpen. Jurnal Pendidikan Surya Edukasi, 2(2), 20 Https://Doi.Org/Https://Doi.Org/10.37729/Jpse.V2i2

Sugiyono. (2017). Metode Penelitian Kuantitatif, Kualitatif, Dan R\&D (Ke-26). Alfabeta.

Tarigan, H. G. (2008). Menulis Sebagai Suatu Keterampilan Berbahasa. Angkasa.

Ulfa, N., Arifin, Z., \& Wijayanti, A. (2019). Keefektifan Model Pembelajaran Picture And Picture Dengan Media Gambar Seri Terhadap Kemampuan Menulis Karangan Sederhana. Journal For Lesson And Learning Studies, 2(2), 267-275. Https://Doi.Org/10.23887/Jlls.V2i2.19155

Wibowo, D. C., Sutani, P., \& Fitrianingrum, E. (2020). Penggunaan Media Gambar Seri Untuk Meningkatkan Kemampuan Menulis Karangan Narasi. Jurnal Studi Guru Dan Pembelajaran, 3(1), 1-7. Https://EJournal.My.Id/Jsgp/Article/View/245

Zulfikar Fu'ad. (2008). Menulis Biografi, Jadikan Hidup Anda Lebih Bermakna! Kiat Ramadhan KH Menul... - Google Books. Pustaka Pelajar. Https://Www.Google.Co.Id/Books/Edition/Menulis_Biografi_Jadikan_Hidup_Anda_Lebi/7uzvqwaacaaj $? \mathrm{Hl}=\mathrm{Id}$ 